This document was prepared in conjunction with work accomplished under Contract No. DE-AC09-96SR18500 with the U. S. Department of Energy.

\title{
DISCLAIMER
}

This report was prepared as an account of work sponsored by an agency of the United States Government. Neither the United States Government nor any agency thereof, nor any of their employees, nor any of their contractors, subcontractors or their employees, makes any warranty, express or implied, or assumes any legal liability or responsibility for the accuracy, completeness, or any third party's use or the results of such use of any information, apparatus, product, or process disclosed, or represents that its use would not infringe privately owned rights. Reference herein to any specific commercial product, process, or service by trade name, trademark, manufacturer, or otherwise, does not necessarily constitute or imply its endorsement, recommendation, or favoring by the United States Government or any agency thereof or its contractors or subcontractors. The views and opinions of authors expressed herein do not necessarily state or reflect those of the United States Government or any agency thereof. 


\section{MAXIMIZING SB3 WASTE THROUGHPUT MELT RATE TESTS (U)}

M. E. Smith

D. H. Miller

August 2005

Immobilization Technology Section

Savannah River National Laboratory

Aiken, SC 29808

Prepared for the U.S. Department of Energy Under Contract Number DEAC09-96SR18500

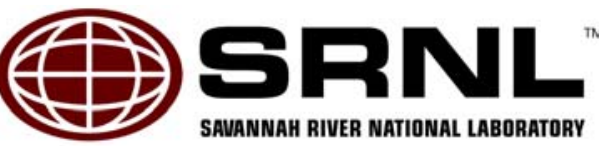

We Put Science To Work 


\title{
DISCLAIMER
}

This report was prepared by Westinghouse Savannah River Company (WSRC) for the United States Department of Energy under Contract No. DE-AC09-96SR18500 and is an account of work performed under that contract. Neither the United States Department of Energy, nor WSRC, nor any of their employees makes any warranty, expressed or implied, or assumes any legal liability or responsibility for the accuracy, completeness, or usefulness, of any information, apparatus, or product or process disclosed herein or represents that its use will not infringe privately owned rights. Reference herein to any specific commercial product, process, or service by trademark, name, manufacturer or otherwise does not necessarily constitute or imply endorsement, recommendation, or favoring of same by WSRC or by the United States Government or any agency thereof. The views and opinions of the authors expressed herein do not necessarily state or reflect those of the United States Government or any agency thereof.

\author{
Printed in the United States of America \\ Prepared For \\ U.S. Department of Energy
}


Key Words: Melt rate, SB3, DWPF, glass

Retention: Permanent

\section{MAXIMIZING SB3 WASTE THROUGHPUT MELT RATE TESTS (U)}

M. E. Smith

D. H. Miller

August 2005

Immobilization Technology Section

Savannah River National Laboratory

Aiken, SC 29808

Prepared for the U.S. Department of Energy Under Contract Number DEAC09-96SR18500

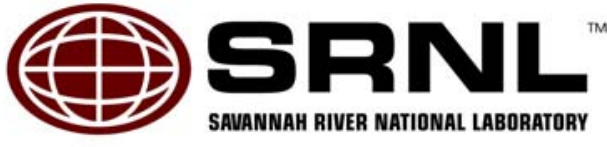

We Put Science To Work 


\section{REVIEWS AND APPROVALS}

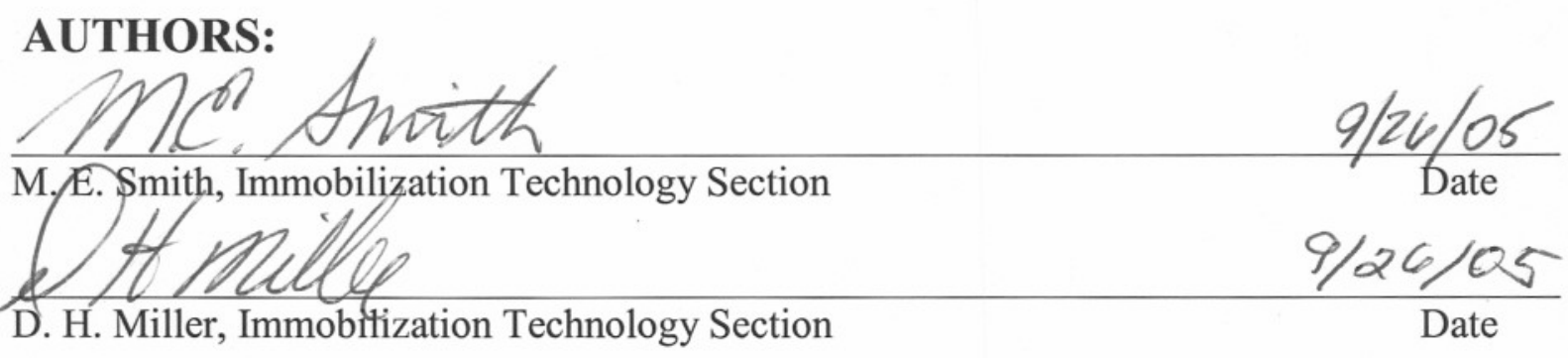

TECHNICAL REVIEWER:

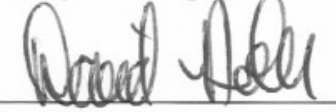

D. K. Peeler, Immobilization Technology Section

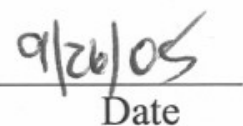

\section{APPROVERS}

Itrhana bo

E. W. Holtzscheiter, Manager, Immobilization Technology Section

Shaven frama

S. L. Marra, Manager, Glass Formulation \& Process Development
$10 / 3 / 05$

Date $9 / 26 / 05$

Date

J. E. Occhipinti, Manager, DWPF Process Engineering $10-5-05$

Date 


\section{EXECUTIVE SUMMARY}

The Defense Waste Processing Facility (DWPF) is presently vitrifying Sludge Batch 3 (SB3) and preparing to process Sludge Batch 4 (SB4) in late 2006 or early 2007. Previous laboratory testing and DWPF operational experience has indicated that the maximum waste throughput peak for the Sludge Batch (SB2) system occurs at a waste loading in the mid-30's. ${ }^{1}$ This trend has been shown as well for SB3 on a lab-scale basis. ${ }^{2}$ These SB3 tests used SRAT product that targeted a REDuction/OXidation (REDOX) of 0.2 and an acid stoichiometry of 135\%. Acid stoichiometry, however, has been shown to impact the melt rate in MRF tests at one waste loading (35\%). ${ }^{2}$ Due to the impact of acid stoichiometry on melt rate, it is possible that the current target acid stoichiometry (155\%) with SB3 may not exhibit the same maximum waste throughput peak, or there may not even be a discernable peak. In fact, current DWPF operational experience with SB3 and Frit 418 has not shown the same drop off in melt rate and hence waste throughput as was observed with SB2 and Frit 320. ${ }^{3}$

The objective of this testing is to determine if increasing the overall alkali content in the feed (via using the higher alkali Frit 320 versus Frit 418 ) will either result in a shift in the waste throughput to higher waste loadings or an increase in the overall waste throughput at waste loadings of interest (31 to $41 \%)$. For these tests, the target SRAT product REDOX was 0.2 and the target acid stoichiometry was 155\% (both are current DWPF feed preparation targets). The incentive for this series of tests stems from a previous SMRF test with SB3/Frit 320 feed which showed an increase in melt rate versus SB3/Frit 418 at 35\% waste loading. ${ }^{4}$ This single data point suggests that overall waste throughput for the SB3/Frit 320 feed system is higher at 35\% waste loading (i.e., the melt rate versus waste loading curve has potentially shifted upward). To address the potential shift in waste throughput, the strategy was to fully characterize the impact of waste loading on melt rate for the SB3/Frit 320 and SB3/Frit 418 systems. This will allow for potential shifts in waste throughput to be assessed via a change in frit composition. Initially, the MRF was utilized. SMRF testing was planned to be run after the MRF tests, but the decision was made to not perform the SMRF tests due to the MRF results. The MRF tests showed that for the SB3/Frit 418 feed system, both melt rate and waste throughput remained fairly constant as waste loading increased from 33-41\%. For the SB3/320 feed system, melt rate did drop with increased waste loading and there was an apparent waste throughput peak at about 35\% waste loading. Waste throughput for the SB3/Frit 320 decreased with increased waste loading. No determination on any shift of the waste throughput peak with the higher alkali Frit 320 could be made as the SB3/Frit 418 feed system tested had no discernable waste throughput peak to compare with the SB3/Frit 320 waste throughput peak.

Melt rate and waste throughput for most waste loadings tested were increased with Frit 320 (when compared to Frit 418). As the waste loading increased, the impact of the higher alkali Frit 320 was lessened as the glass compositions became similar (at 39\% and $41 \%$ waste loadings, melt rate and waste throughput were essentially the same with the two frits). If Frit 320 were used in DWPF, higher waste throughputs could possibly be achieved at about $35 \%$ waste loading, but at this time the emphasis is to run at higher waste loadings (near 40\%) to minimize the number of discrete canisters produced. Indeed, the results indicate that DWPF may be able to increase SB3 waste loading without much of a decrease in waste throughput when using Frit 418. This testing also indicates that it may be possible to process certain future sludge batches at higher waste loadings without negatively impacting waste loading. Testing of each future sludge batch will be required.

Tests were performed with non-radioactive, simulated SB3 material. Due to the small-scale of the test equipment and the design of the equipment, as well as the use of dry, non-radioactive simulant feed, the behavior of the actual radioactive SB3 feed in the DWPF melter cannot be fully proven. 


\section{TABLE OF CONTENTS}

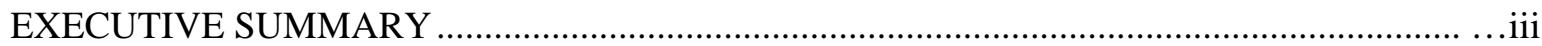

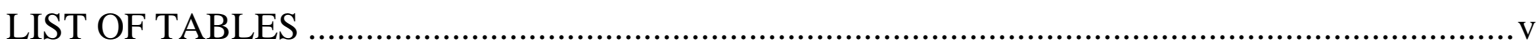

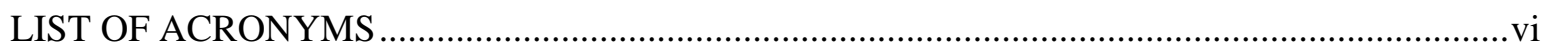

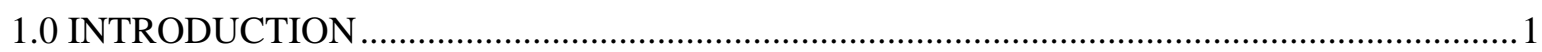

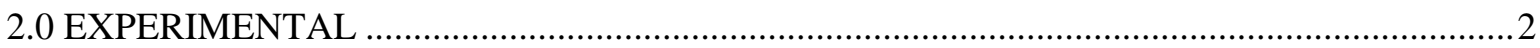

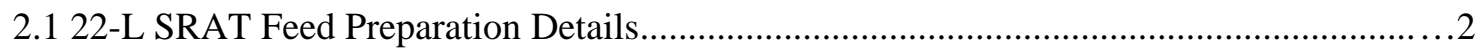

2.2 MRF MWT Testing Details.......................................................

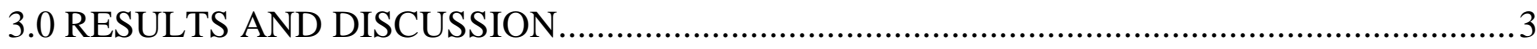

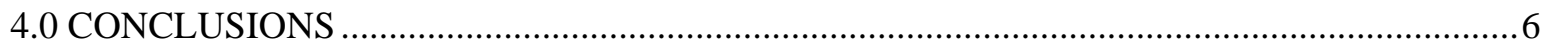

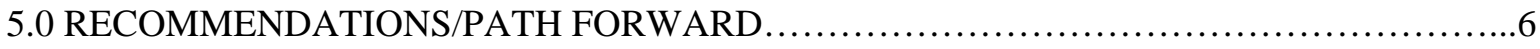

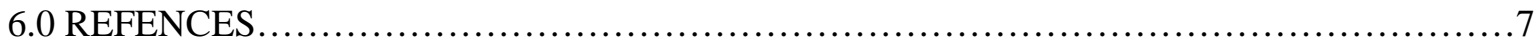

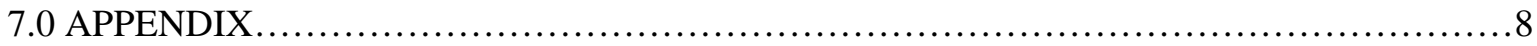




\section{LIST OF TABLES}

Table 2-1. Elemental Analysis and Target Composition of 22-L SRAT Product for MWT Tests.......2

Table 3-1. Linear Melt Rates (Inches/Hr) for the MRF MWT Tests...............................3

Table 3-2. Target and Calculated WL's (Using $\mathrm{Al}_{2} \mathrm{O}_{3}$ and $\mathrm{Li}_{2} \mathrm{O}$ ) for the MRF MWT Tests..............3

\section{LIST OF FIGURES}

Figure 3-1. Impact of Waste Loading on SB3 MRF Linear Melt Rate ........................................4

Figure 3-2. Impact of Waste Loading on WTF's for SB3 with Frits 418 and 320..................5 


\section{LIST OF ACRONYMS}

$\begin{array}{ll}\text { ACTL } & \text { Aiken County Technology Laboratory } \\ \text { DWPF } & \text { Defense Waste Processing Facility } \\ \text { LMR } & \text { Linear Melt Rate } \\ \text { MRF } & \text { Melt Rate Furnace } \\ \text { MWT } & \text { Maximizing Waste Throughput } \\ \text { REDOX } & \text { REDuction/OXidation } \\ \text { SB2 } & \text { Sludge Batch 2 } \\ \text { SB3 } & \text { Sludge Batch 3 } \\ \text { SB4 } & \text { Sludge Batch 4 } \\ \text { SMRF } & \text { Slurry-Fed Melt Rate Furnace } \\ \text { SRAT } & \text { Sludge Receipt and Adjustment Tank } \\ \text { SRNL } & \text { Savannah River National Laboratory } \\ \text { TTR } & \text { Task Technical Request } \\ \text { WL } & \text { Waste Loading } \\ \text { WTF } & \text { Waste Throughput Factor }\end{array}$




\subsection{INTRODUCTION}

The Defense Waste Processing Facility (DWPF) is presently vitrifying Sludge Batch 3 (SB3) and preparing to process Sludge Batch 4 (SB4) in late 2006 or early 2007. Previous laboratory testing and DWPF operational experience has indicated that the maximum waste throughput peak for the Sludge Batch 2 (SB2) system occurs at a waste loading in the mid-30's. ${ }^{1}$ This trend has been shown as well for SB3 on a lab-scale basis. ${ }^{2}$ These SB3 tests used SRAT product that targeted a REDuction/OXidation (REDOX) of 0.2 and an acid stoichiometry of $135 \%$. Acid stoichiometry, however, has been shown to impact melt rate of MRF tests at one waste loading (35\%). ${ }^{2}$ Due to the impact of acid stoichiometry on melt rate, it is possible that the current target acid stoichiometry (155\%) with SB3 may not exhibit the same maximum waste throughput peak, or there may not even be a discernable peak. In fact, current DWPF operational experience with SB3 and Frit 418 has not shown the same drop off in melt rate and hence waste throughput as was observed with SB2 and Frit 320. ${ }^{3}$

The objective of this testing is to determine if increasing the overall alkali content in the feed (via using the higher alkali Frit 320 versus Frit 418 ) will either result in a shift in the waste throughput to higher waste loadings or an increase in the overall waste throughput at waste loadings of interest (31 to 41\%). For these tests, the target Sludge Receipt and Adjustment Tank (SRAT) product REDOX was 0.2 and the target acid stoichiometry was 155\%. The incentive for this series of tests stems from a previous SlurryFed Melt Rate Furnace (SMRF) test with SB3/Frit 320 feed which showed an increase in melt rate versus SB3/Frit 418 at 35\% waste loading. ${ }^{4}$ This single data point suggests that overall waste throughput for the SB3/Frit 320 system is higher at $35 \%$ waste loading (i.e., the melt rate versus waste loading curve has potentially shifted upward). To address the potential shift in waste throughput, the strategy was to fully characterize the impact of waste loading (ranging from about 30 to 40\%) on melt rate for the SB3/Frit 320 and SB3/Frit 418 feed systems. This will allow for potential shifts in waste throughput to be assessed via a change in frit composition. Initially, the dry-fed Melt Rate Furnace (MRF) was utilized. Based on the MRF results, the tests had a decision point on whether or not to continue testing using the SMRF.

This task was initiated by DWPF Engineering via Task Technical Request (TTR) HLW-DWPF-20040030 to the Savannah River Laboratory (SRNL). The work was performed per Task Technical and Quality Assurance Plan WSRC-RP-2004-00713.

Tests were performed with non-radioactive, simulated SB3 material. Due to the small-scale of the test equipment and the design of the equipment, as well as the use of dry, non-radioactive simulant feed, the behavior of the actual radioactive SB3 feed in the DWPF melter cannot be fully proven. 


\subsection{EXPERIMENTAL}

\subsection{2-L Feed Preparation Details}

The SB3 SRAT product for the all of the Maximizing Waste Throughput (MWT) tests was made per run plan SRNL-ITS-2005-00056 in an Aiken County Technology Laboratory (ACTL) 22-L SRAT. The feed preparation process targets were $155 \%$ acid stoichiometry and 0.2 REDOX. The SRAT product identification number was FMPR-0134. The elemental analysis of the SRAT product and the target SB3 surrogate composition are given in Table 2-1. All weight percents are the average of analyses of two samples pulled after the SRAT run. Documentation of the feed preparation run will be documented in a future report.

Table 2-1. Elemental Analysis and Target Composition of 22-L SRAT Product for MWT Tests

\begin{tabular}{||c|c|c||}
\hline ELEMENT & $\begin{array}{c}\text { WT. \% } \\
(\text { CALCINED } \\
\left.1100{ }^{\circ} \mathrm{C}\right)\end{array}$ & $\begin{array}{c}\text { TARGET SB3 } \\
\text { SURROGATE } \\
\text { COMPOSTION }\end{array}$ \\
\hline $\mathrm{Al}$ & 9.07 & 9.57 \\
\hline $\mathrm{Ba}$ & 0.125 & 0.139 \\
\hline $\mathrm{Ca}$ & 2.82 & 2.37 \\
\hline $\mathrm{Cr}$ & 0.144 & 0.153 \\
\hline $\mathrm{Cu}$ & 0.126 & 0.157 \\
\hline $\mathrm{Fe}$ & 26.8 & 28.35 \\
\hline $\mathrm{K}$ & 0.132 & 0.122 \\
\hline $\mathrm{Mg}$ & 2.43 & 2.15 \\
\hline $\mathrm{Mn}$ & 4.57 & 4.07 \\
\hline $\mathrm{Na}$ & 14.8 & 14.05 \\
\hline $\mathrm{Ni}$ & 0.908 & 1.06 \\
\hline $\mathrm{S}$ & 0.413 & 0.35 \\
\hline $\mathrm{Si}$ & 1.07 & 1.04 \\
\hline $\mathrm{Zn}$ & 0.315 & 0.323 \\
\hline $\mathrm{Zr}$ & 0.436 & 0.486 \\
\hline \hline
\end{tabular}

\subsection{MRF MWT Testing Details}

The dry-fed MRF has a cylindrical inner chamber that is approximately 0.5 cubic feet in size, with heating coils winding around the chamber walls. The diameter of the chamber is $\sim 7$ ”, and an insulating sleeve and a $1200 \mathrm{~mL}$ stainless steel beaker (6" deep) were inserted from the top. The tests were conducted with the stainless steel beakers inserted with the sleeve so that the beaker bottom was approximately flush with the top of the uppermost chamber coil. An insulating block was used to cover the beaker. The furnace was heated to $1150^{\circ} \mathrm{C}$ with the top opening covered. Once the furnace reached the setpoint, the cover was removed and the beaker containing sufficient dried, sieved material to produce 525 grams of glass was inserted. After 50 minutes, the beaker was removed from the furnace and allowed to cool to room temperature.

This residence time in the furnace was determined during testing in 2002 to establish a standard test time for melt rate comparison for this dry-fed furnace. ${ }^{1}$ After cooling down, the beakers are then sectioned. The relative melt rate is determined by measuring the height of the glass layer in the bottom of each sectioned beaker at 0.25 ” intervals. The average height and duration in the furnace is used to yield a relative linear melt rate number (inches/hour). General observations of the sectioned beaker are also used to describe differences between runs. 


\subsection{RESULTS AND DISCUSSION}

The MWT MRF tests for SB3/Frit 320 were run between April 6 and April 8, 2005. The SB3/Frit 418 tests were run on April 12 and April 13, 2005. The linear melt rates (LMR, expressed in inches/hour) for the two tests are given in Table 3-1. From past MRF testing experience ${ }^{1,2}$, it appears that the LMR's for the 37\% waste loading tests for both Frit 418 and Frit 320 are suspect as melt rate usually either remains the same or drops with increasing waste loading. For the Frit 418 test at $37 \%$ waste loading, the LMR is too low when compared to the 35,39 , and $41 \%$ waste loading tests. For the Frit 320 test at $37 \%$ waste loading, the LMR is too high when compared to the 33 and 35\% waste loading tests.

Table 3-1. Linear Melt Rates (Inches/Hr) for the MRF MWT Tests

\begin{tabular}{||c|c|c||}
\hline $\begin{array}{c}\text { WASTE } \\
\text { LOADING }\end{array}$ & $\begin{array}{c}\text { SB3/FRIT 418 } \\
\text { (LMR) }\end{array}$ & $\begin{array}{c}\text { SB3/FRIT 320 } \\
\text { (LMR) }\end{array}$ \\
\hline 31 & 0.59 & 0.67 \\
\hline 33 & 0.50 & 0.59 \\
\hline 35 & 0.51 & 0.60 \\
\hline 37 & 0.41 & 0.67 \\
\hline 39 & 0.47 & 0.48 \\
\hline 41 & 0.48 & 0.45 \\
\hline
\end{tabular}

Due to these apparent outliers, glass samples from each test were taken and analyzed to determine if there were any batching problems for the tests. The results of the analyses are given in the Appendix. Waste loadings (WL) were calculated for each glass by using the analyzed weight percents of both $\mathrm{Al}_{2} \mathrm{O}_{3}$ and $\mathrm{Li}_{2} \mathrm{O}$. The target and measured waste loadings using these two oxides are given in Table 3-2. The formulas used to calculate waste loading using both oxides are given below. All weight percents cited are normalized. The weight percent of $\mathrm{Al}_{2} \mathrm{O}_{3}$ in the sludge was $17.8 \%$. The weight percents of $\mathrm{Li}_{2} \mathrm{O}$ in the Frit 418 and 320 used were both 7.91\%.

Table 3-2. Target and Calculated WL's (Using $\mathrm{Al}_{2} \mathrm{O}_{3}$ and $\mathrm{Li}_{2} \mathrm{O}$ ) for the MRF MWT Tests

\begin{tabular}{||c|c|c|c|c||}
\hline $\begin{array}{c}\text { TARGET } \\
\text { WL }\end{array}$ & $\begin{array}{c}\text { SB3/FRIT 418 } \\
\text { CALCULATED } \\
\text { WL (Al } \mathbf{O}_{3} \\
\text { METHOD) }\end{array}$ & $\begin{array}{c}\text { SB3/FRIT 418 } \\
\text { CALCULATED } \\
\text { WL (Li } \mathbf{~ O ~} \\
\text { METHOD) }\end{array}$ & $\begin{array}{c}\text { SB3/FRIT 320 } \\
\text { CALCULATED } \\
\text { WL (Al } \mathbf{O}_{3} \\
\text { METHOD) }^{\text {METHOD }}\end{array}$ & $\begin{array}{c}\text { SB3/FRIT 320 } \\
\text { CALCULATED } \\
\text { WL (Li } \mathbf{~ O ~} \\
\text { METHOD) }^{\text {METHOD }}\end{array}$ \\
\hline 31 & 32.8 & 29.0 & 32.6 & 32.4 \\
\hline 33 & 35.0 & 30.5 & 34.7 & 33.8 \\
\hline 35 & 36.2 & 32.2 & 36.5 & 34.8 \\
\hline 37 & 39.1 & 35.7 & 37.7 & 34.9 \\
\hline 39 & 40.0 & 35.8 & 41.0 & 38.1 \\
\hline 41 & 41.8 & 37.2 & 43.3 & 39.5 \\
\hline
\end{tabular}

Waste Loading (via $\mathrm{Al}_{2} \mathrm{O}_{3}$ Method) $=\left(\mathrm{Wt} \% \mathrm{Al}_{2} \mathrm{O}_{3}\right.$ Feed $/ \mathrm{Wt} \% \mathrm{Al}_{2} \mathrm{O}_{3}$ Sludge $)$ x $100 \%$

Waste Loading (via $\mathrm{Li}_{2} \mathrm{O}$ Method $)=\left(1-\left(\mathrm{Wt} \% \mathrm{Li}_{2} \mathrm{O}\right.\right.$ Glass $/ \mathrm{Wt} \% \mathrm{Li}_{2} \mathrm{O}$ Frit $\left.)\right) \times 100 \%$

In general, the calculated waste loadings did increase as the targeted waste loadings increased. Depending on the oxide used to calculate melt rate, one could argue that indeed the SB3/Frit 418 at 37\% waste loading test had a higher than targeted waste loading (39.1\% using $\mathrm{Al}_{2} \mathrm{O}_{3}$ ) that would result in a lower melt rate, while the SB3/Frit 320 at 37\% waste loading test had a higher than targeted waste 
loading (34.9\% using $\mathrm{Li}_{2} \mathrm{O}$ ) that would result in a higher melt rate. This logic does not work well, however, if both waste loading calculations are considered equal or if melt rates from similar calculated waste loadings (for example the melt rates for SB3/Frit 320 at targeted waste loadings of 35 and 37\% via the $\mathrm{Li}_{2} \mathrm{O}$ method) are compared (34.8 and 34.9 inches/hr.). In addition, the relative amounts of $\mathrm{Na}_{2} \mathrm{O}$ and $\mathrm{SiO}_{2}$ were compared with increasing waste loading for both tests. Both trended correctly as $\mathrm{Na}_{2} \mathrm{O}$ increased and $\mathrm{SiO}_{2}$ decreased with increasing waste loading.

After reviewing all of the data, it was decided that the best way to plot the results was to average the melt rates for the 35 and 39\% waste loadings for the two frits tested and then use the averages for the 37\% waste loading melt rates. As discussed before, part of the decision was based on past impact of waste loading MRF tests. This resulted in calculated linear melt rates of 0.49 and 0.54 inches/hr respectively for the SB3/Frit 418 and SB3/Frit 320 for the 37\% waste loading MRF tests. With these results, the impact on melt rate for the two feeds from increasing waste loading is plotted in Figure 3-1.

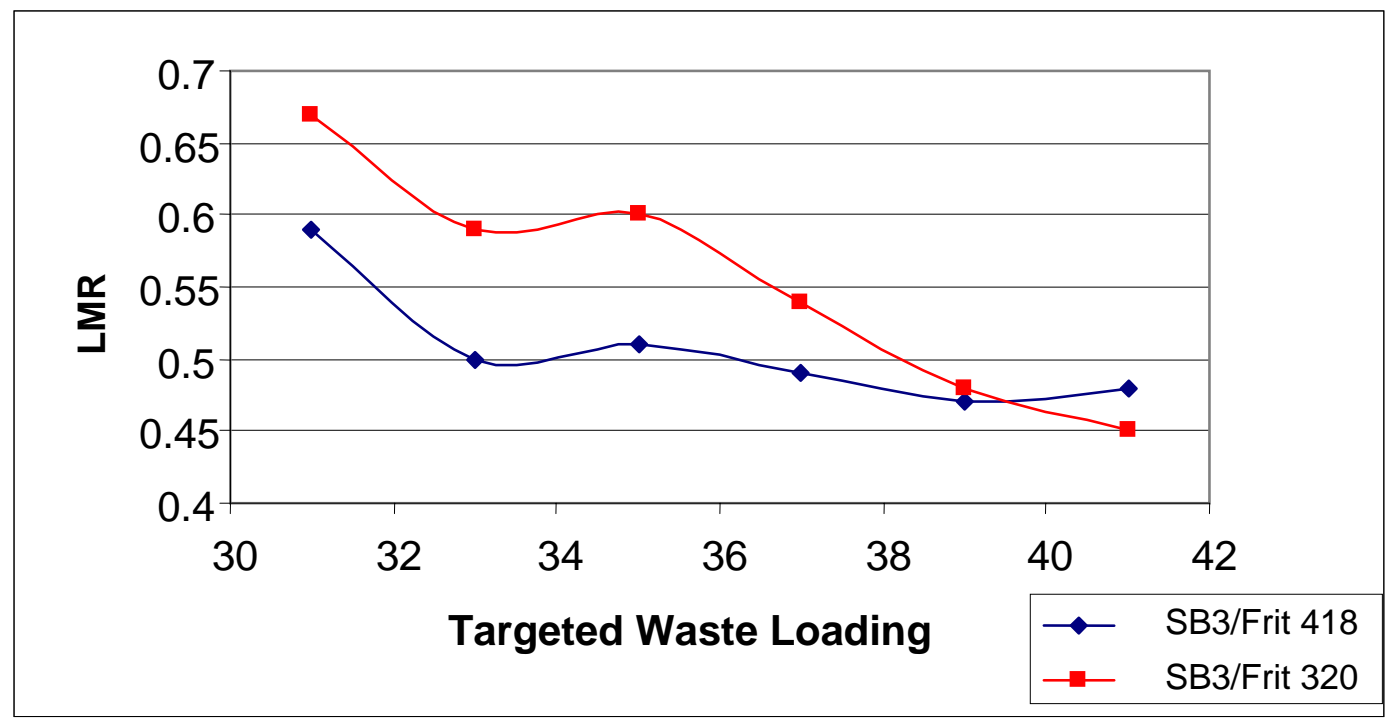

Figure 3-1. Impact of Waste Loading on SB3 MRF Linear Melt Rate*

* Note: Used calculated LMR’s for 37\% waste loading values for both Frit 418 and Frit 320

Figure 3-1 shows that melt rate for the SB3/Frit 320 feed decreased as waste loading increased as has been observed in previous MRF waste loading tests for SB2 ${ }^{1}$ and SB3/Frit $418 .^{2}$ For the SB3/Frit 418 feed, however, the melt rate was not lowered much with increasing waste loading (after $31 \%$ waste loading). This contradicts the previous SB3/Frit 418 MRF melt rate results. ${ }^{2}$ These previous SB3/Frit 418 MRF tests, however, used a SRAT with a targeted acid stoichiometry of $135 \%$. Acid stoichiometry has been shown to impact the melt rate of MRF tests at one waste loading (35\%). ${ }^{2}$ Therefore, it is possible that the MRF melt rate trends previously observed with SB3/Frit 418 at 135\% acid stoichiometry may not be exhibited with the same feed at an acid stoichiometry of $155 \%$. The relative lack of drop in melt rate seen with SB3/Frit 418 as shown in Figure 3-1 would indicate that it may be possible to operate at higher waste loadings at DWPF with SB3 and Frit 418 (at the current 155\% acid stoichiometry) without much loss in melt rate. As was expected, the melt rates for the higher alkali Frit 320 were higher than Frit 418 for the same waste loadings. This was true up to 39\% waste loading when melt rates for both frits with SB3 converge. This is because as the waste loading goes up the feed/glass compositions for the two feed systems become more similar. This is due to the fact that the feed/glass composition is increasingly dominated by the sludge composition.

This melt rate data was then used to determine the Waste Throughput Factor (WTF) for the various tests. WTF is a measure of the rate that waste can be processed and is calculated by the following formula. 


$$
\mathrm{WTF}=\mathrm{LMR} \text { (inches/hr) } \mathrm{x} \text { WL }
$$

For example, a MRF test with a LMR of 0.5 inches per hour and a waste loading (WL) of 35\% would have a resultant WTF of 17.5. WTF's can be used to compare relative waste throughputs of various feeds (no matter which sludge, frit, waste loading, REDOX, etc). Figure 3-2 gives the WTF's for these tests as a function of waste loading. Target waste loadings are used in the WTF values cited.

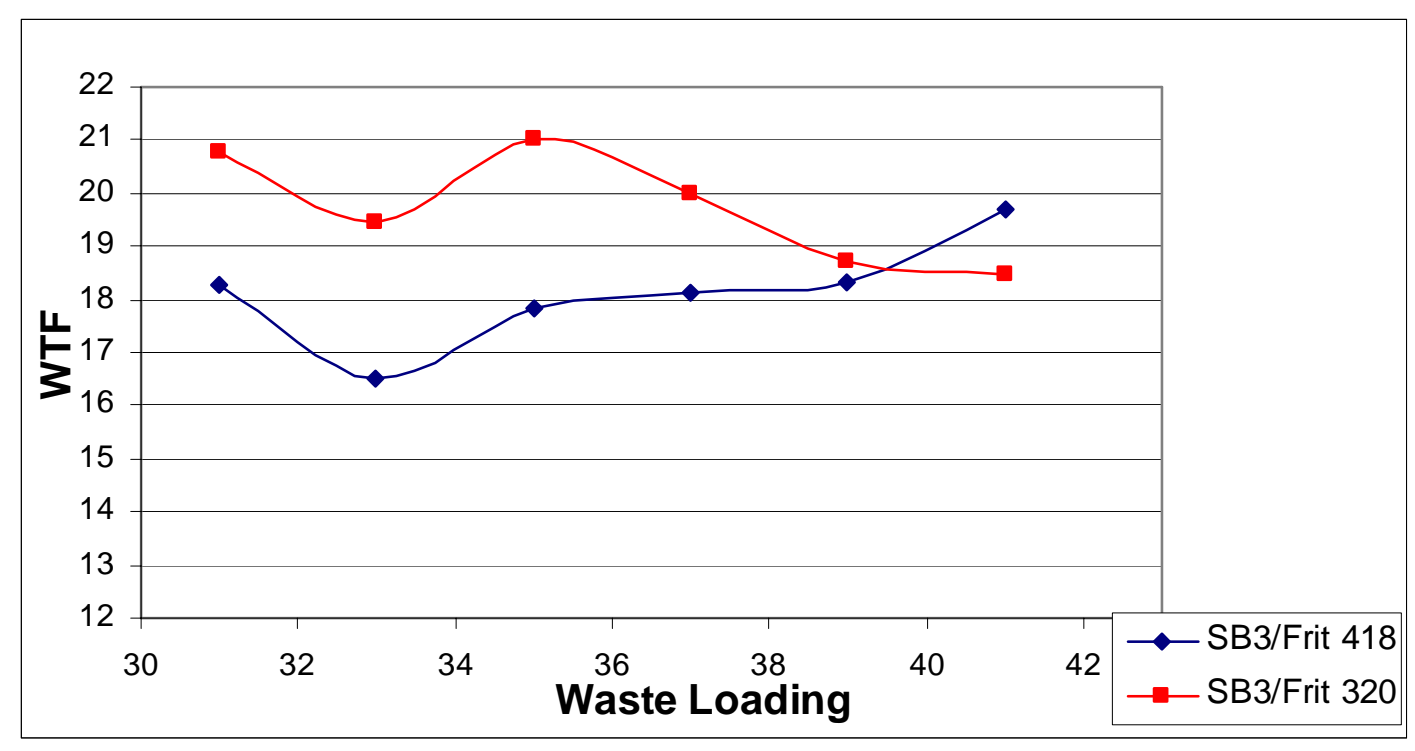

Figure 3-2. Impact of Waste Loading on WTF's for SB3 with Frits 418 and 320

Figure 3-2 shows that there does not appear to be a waste throughput peak for SB3/Frit 418. Waste throughput remained about the same as waste loading increased. The SB3/Frit 320 feed system may have a waste throughput peak in the mid-30's waste loading that drops off as waste loading is increased. If Frit 320 were used in DWPF, higher waste throughputs could possibly be achieved at about 35\% waste loading, but at this time the emphasis is to run at higher waste loadings (near $40 \%$ ) to minimize the number of discrete canisters produced. Indeed, the results indicates that DWPF may be able to increase SB3 waste loading without much of a decrease (if any) in waste throughput when using Frit 418. As with the melt rates, the waste throughputs for the two different frits become similar with increasing waste loading. Therefore there appears to be no benefit to use Frit 320 (versus Frit 418 which is now being used at DWPF) at the higher waste loadings now being targeted at DWPF. Finally, no comparison in the shift in the waste throughput peak could be made as no peak was observed for the SB3/Frit 418 feed system.

With these findings, as well as the recent increase in the targeted DWPF waste loading late in FY05 to around $40 \%$, it was decided to not perform the SMRF MWT tests. MWT tests should be runs for future sludge batches, as the results may show that unlike these results for SB3, certain frits shift waste throughput to higher waste loadings. 
WSRC-TR-2005-00456

\subsection{CONCLUSIONS}

The following conclusions can be made with regards the SB3 Maximizing Waste Throughput MRF melt rate tests:

- Melt rate for the SB3/Frit 320 feed decreased as waste loading increased as has been observed in previous MRF waste loading tests for this system. ${ }^{1}$ For the SB3/Frit 418 feed, however, the melt rate was not lowered much with increasing waste loading (after $31 \%$ waste loading). This contradicts previous MRF testing with SB3/Frit 418. ${ }^{2}$ The main difference between these two SB3/Frit 418 tests was the targeted acid stoichiometry for the SRAT product. The previous tests targeted $135 \%$, while the tests in this report used the current DWPF acid stoichiometry target of 155\%. Previous MRF tests showed that acid stoichiometry does impact melt rate at one waste loading (35\%), so it is possible that a different trend could occur due to a change in the targeted acid stoichiometry.

- As was expected, the melt rates for the higher alkali Frit 320 were more than those for Frit 418 at the same waste loadings. This was true up to $39 \%$ waste loading when melt rates for both frits with SB3 converge. This is because as the waste loading goes up the feed/glass compositions for the two feed systems become more similar.

- There does not appear to be a waste throughput peak for SB3/Frit 418 for the range of waste loadings tested. Waste throughput remained about the same as waste loading increased.

- $\quad$ The SB3/Frit 320 feed system has a waste throughput peak in the mid-30's waste loading.

- If Frit 320 were used in DWPF with SB3, higher waste throughputs could possibly be achieved at about $35 \%$ waste loading, but at this time the emphasis is to run at higher waste loadings (near $40 \%)$ to minimize the number of discrete canisters produced.

- With regards to SB3/Frit 418 melt rate only, the observed "flat" trend in melt rate at $155 \%$ acid stoichiometry would indicate that it may be possible to operate at higher waste loadings at DWPF with SB3/Frit 418. In addition, The test results indicate that DWPF may be able to increase SB3 waste loading without much of a decrease in waste throughput when using Frit 418.

- As with the melt rates, the waste throughputs for the two different frits become similar with increasing waste loading as the glass compositions become more similar.

\subsection{RECOMMENDATIONS/PATH FORWARD}

The following recommendations/path forward are given as a result of the findings of the SB3 Maximizing Waste Throughput MRF melt rate tests:

- MWT tests should be runs for future sludge batches, as the results may show that unlike these results for SB3, certain frits shift waste throughput to higher waste loadings. 


\subsection{REFERENCES}

1. Lorier, TH, TM Jones, DC Witt. 2002. Melt Rate Testing for the DWPF: Summary of FY02 Testing, WSRC-TR-2002-00545, Westinghouse Savannah River Company, Aiken, South Carolina.

2. Lorier, TH and ME. Smith. 2004. Melt Rate Assessment of SB2/3 with Frit 418 - Effects of Waste Loading and Acid Stoichiometry, WSRC-TR-2004-00098, Westinghouse Savannah River Company, Aiken, South Carolina.

3. Smith, ME. 2003. DWPF SB2/Frit 320 Melt Rate (U), SRT-GPD-2003-00045, Westinghouse Savannah River Company, Aiken, South Carolina.

4. Smith, ME, DH Miller, and TM Jones. 2004. Slurry-Fed Melt Rate Furnace Test for the SB3/Frit 320 Feed System, WSRC-TR-2004, Westinghouse Savannah River Company, Aiken, South Carolina. 
APPENDIX - ANALYSES OF MWT MRF GLASS AND CALCULATED WASTE LOADINGS USING $\mathrm{Li}_{2} \mathrm{O}_{\text {and } \mathrm{Al}_{2} \mathrm{O}_{3}}$

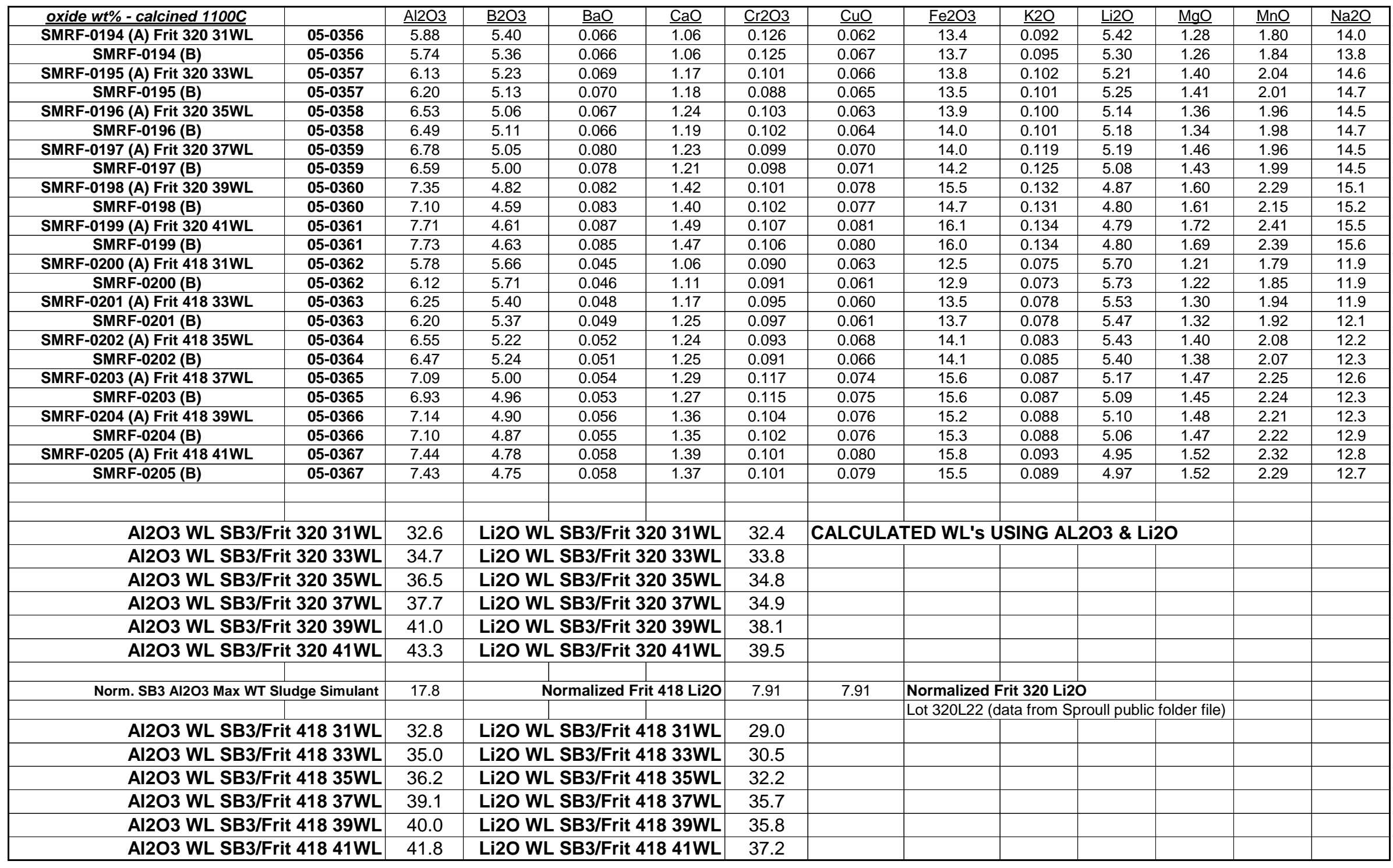




\section{Distribution:}

J. E. Marra, SRNL

E. W. Holtzscheiter, SRNL

N. E. Bibler, SRNL

C. M. Jantzen, SRNL

G. C. Wicks, SRNL

T. L. Fellinger, SRNL

D. A. Crowley, 999-W

S. L. Marra, 999-W

T. B. Calloway, 999-W

J. R. Harbour, 773-42A

C. A. Langton, 773-43A

M. E. Smith, 773-42A

D. H. Miller, 786-1A

T. M. Jones, 999-W

D. K. Peeler, 999-W

C. C. Herman, 773-42A

M. E. Stone, 999-W

A. S. Choi, 773-42A

M. S. Miller, 704-S

A. B. Barnes, 704-30S

J. E. Occhipinti, 704-S

R. M. Hoeppel, 704-27S

J. F. Iaukea, 704-30S

D. C. Iverson, 704-30S

R. J. O’Driscoll, 704-30S

J. W. Ray, 704-S

F. A. Washburn, 704-27S 